\title{
A Study on the Relation between the Demographics of Human Resource Managers in Turkey and Characteristics of their Companies
}

\author{
Riza Demir (Corresponding Author) \\ Istanbul University, Avc1lar Campus, 34320, Avcilar, Istanbul, Turkey \\ E-mail: rdemir@istanbul.edu.tr
}

Cavide Uyargil

Istanbul Kultur University, Atakoy Campus, 34156, Bakirkoy, Istanbul, Turkey

E-mail: cuyargil@istanbul.edu.tr

Received: Oct. 10, 2017 Accepted: Oct. 23, 2017 Online published: Oct. 28, 2017

doi:10.5296/ijhrs.v7i4.11977ＵRL: https://doi.org/10.5296/ ijhrs.v7i4.11977

\begin{abstract}
The demographics of HR managers have been a matter of discussion for a long time. Most frequently encountered comments include; those that work in the field of HRM are generally female, those that have a Bachelor's Degree in business administration or economics, psychology, the humanities or law and those that have Master's Degree, have more work experience or those that are transferred from other companies are mostly employed in HRM. A more in-depth analysis may be obtained by the comparing the demographics of HR managers with the characteristics of their organizations. In this context, the purpose of the study is to first determine the demographics of HR managers and whether there is a relation between the demographics and the characteristics of their organizations in Turkey. The data were obtained through "using available information" on corporate websites, various databases and social networking sites. The findings of the study show that there is relation between the demographic factors of human resource managers such as gender, education background, total work experience, and the way that they are appointed to their current position, and the characteristic factors of their organizations such as segment, sector, partnership, year of establishment, and legal status.
\end{abstract}

Keywords: HR manager, demographics, organization, characteristics, relation 


\section{Introduction}

Human should be considered as a factor in the organizations where certain resources come together in order to produce any kind of assets or service. In an organization the term of "Human Resource (HR)" implies all employess from the highest position to the lowest. Human is in constant interaction with the environment, being affected by the surrounding incidents with the ability to give different reactions to different conditions. Therefore, human needs to be evaluated separately from the other production factors.

The HR managers which are mainly in charge of HR practices should have certain skills such as communication, innovation, flexibility, leadership in order to be competitive and advantageous while using the human factor. In addition to these, the segment that the organizations operate, the sector, the business field, partnership structure and legal status could be considered as the effective factors on determining the profile of HR managers. These characteristics of organizations may lead to a demand for HR managers with different demographics. For that reason it should be aimed to investigate whether there is a relation between characteristics of organizations and the demographics of HR managers.

In the first part of this study, the nature of human resource management (HRM) and the role and responsibility of HR managers are researched and the results of a number of studies are reviewed. In the second part of the study the data of the demographics of some HR managers and the characteristics of their organizations in Turkey are presented. In the final part; the results of the analysis on the relations between the demographics of HR managers and characteristics of organizations are presented.

\section{The Nature of HR Function in the Organizations}

Human resource management (HRM) is commonly used in two different ways. On one hand, it refers to a collection of policies used to organize the work concerning the employment relations and the management of work and the management of people who undertake this work (Beardwell \& Claydon, 2010, p. 4). Used in this way, HRM is really no more than a modern and supposedly imposing name for what has long been labelled "personnel management" (Torrington, Hall \& Taylor, 2008, p. 6). On the other hand, the term is equally widely used to denote a particular approach to the management of people which is clearly distinct from personnel management. When it is used in this way, HRM refers to the policies, practices and systems that influence the behavior, attitudes, and performance of employess (Noe, Hollenbeck, Gerhart \& Wright, 2008, p. 4).

Human resources management consists of numerous practices, including equal employment opportunity (EEO) compliance, job analysis, human resource planning, employee recruitment, selection, motivation, orientation, performance evaluation and compensation, training and development, labor relations and safety, health and wellness (Ivancevich, 2010, p. 5). Carrying out these practices are under the role and responsibility of high position managers, expert divisions, HR managers and other line managers. Recently; the importance of line managers in effective application of HRM functions is increasing. The results of a study conducted in India provide ample support to the idea that involvement of line manager in 
HRM has positive implications and favourable outcomes (Azmi \& Mushtaq, 2015, p. 633). Also it is stated that the effective application of HRM practices is in close contact with line managers' efficacy and motivation, as well as the suitable environment increases this effect (Bos-Nehles, Van Riemsdijk \& Looise, 2013, p. 861). And it is revealed that, different line managers preferred different HR applications; for instance a line manager with transformational leadership style mostly used loyalty based HR applications in his department (Vermeeren, 2014, p. 3052).

\section{The Role and Responsibility of HR Managers}

HRM is simply a way of grouping together the range of activities associated with managing people that are variously categorized under employee relations, industrial/labour relations, personnel management, and organizational behaviour (Heery and Noon, 2008, p. 214). Human resources staff (the size of HR department) component is affected not only by organizational size but also by sector and national location (Brewster, Wood, Brookes \& Van Ommeren, 2006, p. 3). The role and responsibility of HR practitioners varies depending on whether they are managers or experts, their level of position, the needs of the organization, the work that they carry out and their capacity (Armstrong, 2009, p. 105; Dessler, 2011, p. 33-34).

The expectations from HR managers has increased along with the changes such as globalization, competition, technology, workforce trends, and economic turmoils. Today organizations expect HR managers to "focus on the big picture (informing and supporting the top management about strategy and vision)", "find new ways to fulfill operational activities (using new technologies and external sources)", and "have new abilities". HR managers have been ascribed the role of "architects" who can foster the development of capabilities that support HRM implementation by allocating resources to learning activities (Piening, Baluch \& Ridder, 2014, p. 562).

In recent years HR managers have been encouraged to play a more strategic role in their organizations, especially in the case of extensive organizational change processes such as international mergers and acquisitions. Today this requirement is even more acute since the past decade has been characterized by enormous growth in mergers and acquisitions (Antila, 2006, p. 999). In strategic HRM, the focus should be on HR applications' contribution to organizational performance and competitive advantage (Mitchell, Obeidat \& Bray, 2013, p. 900). Through strategic HRM, HRM has obtained a strategic meaning rather than a support service that can be claimed and while HRM focuses on "how" to manage the human resource, strategic HRM focuses on "what" the organization does using human resource (Ngo, Lau \& Foley, 2008, p. 73).

\section{The Demographics of Human Resource Managers}

The demographics of HR managers have also been discussed for a long time. Most frequently encountered comments include; those that work in the field of HRM are generally female, graduates of certain universities or certain departments; also the ones who have master's degree in certain departments are mostly employed. A college degree is held by the vast 
majority of HRM professionals, many of whom also have completed postgraduate work. Business typically is the field of study (human resources or industrial relations), although some HRM professionals have degrees in the social sciences (economics or psychology), the humanities, or law. Those who have completed graduate work have master's degrees in HR management, business management or a similar field. (Noe et al., 2008, p. 12).

In a study, it has been found that the HR managers working in Turkey are mainly male, they have a work experience of 5-15 years, and generally they have bachelor's degree in the departments of business administration or engineering (Uyargil \& Özçelik, 2001). According to the study, the demographics of Turkish HR managers share the highest similarity with their counterparts in Germany while the least similarity with the ones in the UK.

In another study conducted in 2010, 65\% of the workers in HR in Turkey are female and the number of engineering -especially industrial engineering- graduates is estimated to be increasing in the departments of HR. It is indicated that graduates of the mathematical disciplines and the departments such as psychology, sociology, international relations, and public administration which relatively include occupational knowledge of HR management are choosing HR field more frequently ("OneDergi," 2010). As a result of the study conducted on 1109 HR managers throughout USA who are members of National Society for Human Resource Management - SHRM; it is found that $62 \%$ of all HR managers are female, $44 \%$ of them had bachelor's degree, $24 \%$ of them had master's degree and \%30 of the HR managers work in the health sector (Giannantonio \& Hurley, 2002, p. 191). According to the results of another study, the ratio of female personnel in the field of HRM was 64\% in 1987 which reached to $76 \%$ in 2002 (Kochan, 2004, p. 14). A different study shows that female personnel ratio in HRM was 23\% in 1988 and increased to 54\% in 2007 ("Human Resource Competency Study Executive Summary," 2007, p. 2). The study conducted by the North East Human Resources Association and Human Resources Professionals Association in 2009 with 2.300 people revealed that more than $80 \%$ of the HR personnel who are member of the association were female and 55\% had bachelor's degree, $12 \%$ had master's degree, while $1 \%$ had doctoral degree; $24 \%$ had 6-10 years of experience and $16 \%$ of them were working in the manufacturing sector (Human Resources Professionals Association [HRPA], 2009). In a study conducted throughout the world with 4.300 HR managers, it has been observed that $59 \%$ of the HR leaders and $52 \%$ of the HR managers were female; $34 \%$ of the HR leaders had more than 10 years of experience and $25 \%$ were in industrial manufacturing sector (Page, 2013, p. 37).

\section{Research Context and Method}

The studies on demographics of HR managers are as a matter of fact, scarce and there are no studies that examine the relation between demographics of HR managers and characteristics of organizations. When the studies in HRM are reviewed it is observed that the focus is mostly on the strategic aspect of HRM, the duties and responsibilities of line managers and the employees' perceptions towards HRM practices (Sumelius, Björkman, Ehrnrooth, Mäkelä \& Smale, 2014; Yılmaz \& Ömürgönülşen, 2013; Özutku \& Çetinkaya, 2012; Gürbüz, 2011; Demirtaş, 2014; Demirtaş, 2013; Y1lmaz \& Karahan, 2014; Tastard, 2012; Long, 2008; 
Jamshidi, Zeinahvazi, Aadal \& Sabet, 2012).

The main purpose of this research is to determine that there is a possible correlation between the demographics of HR managers (board members responsible from HR, HR coordinators or HR managers) and the characteristics of their organizations. Accordingly, gender, education and total work experience of HR managers and the way they were appointed to their current position were tried to be determined. Also the characteristics of organizations such as status, segment, sector, partnership structure, year of establishment, and legal status were determined.

\subsection{Data Collection Method}

In this research, the factual data on the specific characteristics of persons and organizations is utilized. The factual data are collected through the method of "using available information" which is one of the social sciences research methods, and secondary data sources are used in order to collect the related data. In order to collect data from sources with a standart classification, an evaluation form was prepared. Evaluation form has two categories: (1) demographics of HR managers and (2) characteristics of organizations. Four sub-categories were used to describe the demographics of HR managers: gender, types of education, total work experience and how they were appointed to the current position. Under the sub-category of types of education, a third level sub-categories were defined such as bachelor's, master's or doctoral degree, location and status of university, faculty etc. And five sub-categories were used to describe the characteristics of organizations: segment, sector, partnership structure, the year of establishment and the legal status of the organizations.

During the collection of data using the evaluation forms, the corporate websites of the companies were visited and the information about the characteristics of organizations was collected. Organizations of which websites did not provide sufficient information, other sources such as Central Database Service Provider (https://e-sirket.mkk.com.tr/esir/), Public Disclosure Platform (http://www.kap.gov.tr), Kompass Information Delivery Services (http://tr.kompass.com/), Kariyer.net Electronic Publication and Communication Services (www.kariyer.net) and social networking sites such as Facebook, Linkedin, Twitter were utilized. After the characteristics of organizations were collected, HR managers of each organization were determined and the information about demographics of those were collected. First, corporate websites were examined, second, social networking sites, primarily Linkedin, and respectively Facebook, Twitter, Xing, Yatedo; and magazine, bulletin, websites such as Career Magazin (http://www.dijimecmua.com/kariyer/), and HR Magazine (http://www.hrdergi.com) were utilized.

\subsection{Population and Sample Size}

The population of research targets joint-stock or limited limited liability or service companies and their HR managers. In order to determine the population, the list of top 500 companies published by Istanbul Chamber of Industry (ICI) in 2014 for joint-stock or industrial limited liability companies were used while various other lists by sectors were utilized for joint-stock or limited service companies. For instance, the finance corporations list of Banking 
Regulation and Supervision Agency, the media companies list of Media Organization, the five star hotels list of Touristic Hotels and Investors Association, the private hospitals list of Social Security Institution and the private universities list of the Council of Higher Education were used to determine the service companies in the population. Also the population of research includes publicly-traded companies in Borsa İstanbul.

The sample of research consists of 647 organizations and their HR managers selected via stratified sampling, which all companies in sub-populations had the equal possibility of selection, considering the proportions of those stratas in population in reference to the calculated sample size. 316 companies are included in the list of top 500 companies published by Istanbul Chamber of Industry (ICI) in 2014. Rest of the sample (331 companies) were reached making use of social networking and other websites. In selection of the sample, that the characteristics of organizations were derived from corporate websites or other websites, while the demographics of their HR managers were derived from social networking sites such as Linkedin, Facebook, Twitter, Xing, Yatedo or magazine and bulletin websites.

\subsection{Limitations}

The failure to access HR managers in all of the companies which are active in Turkey is the limitation of this study. Additionally demographic information of HR managers was limited to what they shared at the social networking sites. For example since they did not share information such as "age", "salary", or "marital status" these variables were not included in the scope of the research.

\subsection{Data Analysis}

All of the data were codified based on a nominal scale which enables to choose a single choice among more than one alternatives and the codes were transferred to SPSS version 18. Coding frame was restructured after the coding was completed and coding was done in accordance with this new frame one more time. The codified data was reanalyzed in SPSS 18.0, and frequency tables were extracted, and for each main and sub-category -spatial frequencies were obtained.

In order to find out relationship, Chi-Square Analysis was conducted. Hypothesis for testing the relation can be specified as follows:

$\mathrm{H}_{1}$ : There is a relation between the segment in which organizations operate and the demographics of HR managers.

$\mathrm{H}_{2}$ : There is a relation between the sector of the organizations and the demographics of $\mathrm{HR}$ managers.

$\mathrm{H}_{3}$ : There is a relation between the partnership structure of the organizations and the demographics of HR managers.

$\mathrm{H}_{4}$ : There is a relation between the year of establishment of the organizations and the demographics of HR managers.

$\mathrm{H}_{5}$ : There is relation between the legal status of the organizations and the demographics of 
HR managers.

\section{Findings}

The findings about characteristics of 647 organizations; demographics of their HR managers and whether there is a relation are presented separately.

\subsection{Characteristics of Organizations}

Characteristics of 647 organizations can be seen on Table 1 .

Table 1. The characteristics of organizations

\begin{tabular}{|c|c|c|c|}
\hline & & $\mathrm{n}$ & $(\%)$ \\
\hline \multirow{2}{*}{ The segment } & Industry & 373 & 57,7 \\
\hline & Service & 274 & 42,3 \\
\hline \multirow{11}{*}{ The sector } & Petro-chemistry & 62 & 9,6 \\
\hline & Metal products-vehicles & 81 & 12,5 \\
\hline & Basic metal industry-energy & 62 & 9,6 \\
\hline & Food, beverage and tobacco & 64 & 9,9 \\
\hline & Manifacturing industry & 57 & 8,8 \\
\hline & Textile & 46 & 7,1 \\
\hline & Wholesale and retail trade & 23 & 3,6 \\
\hline & Financial services & 92 & 14,2 \\
\hline & $\begin{array}{l}\text { Information } \\
\text { technology-communication-transportation }\end{array}$ & 54 & 8,3 \\
\hline & Education/Health/Media & 57 & 8,8 \\
\hline & Tourism and accommodation & 49 & 7,6 \\
\hline \multirow{3}{*}{ The partnership structure } & Domestic capital & 422 & 65,2 \\
\hline & Foreign capital & 202 & 31,2 \\
\hline & Equally-owned & 23 & 3,6 \\
\hline \multirow{5}{*}{ The year of establishment } & Before 1968 & 133 & 20,6 \\
\hline & 1968 and 1983 & 126 & 19,5 \\
\hline & 1984 and 1992 & 130 & 20,1 \\
\hline & 1993 and 2000 & 133 & 20,6 \\
\hline & After 2000 & 125 & 19,3 \\
\hline \multirow{3}{*}{ The legal status } & Joint-stock company & 574 & 88,7 \\
\hline & Limited liability company & 48 & 7,4 \\
\hline & Others & 25 & 3,9 \\
\hline TOTAL & & 647 & 100 \\
\hline
\end{tabular}

When the results are examined it is revealed that among the 647 organizations, 373 are industry companies while 274 are service. 92 organizations are in finance sector, 81 are in metal products-transportation vehicles and 64 are in food, drink and tobacco. When we look at the partnership structure; 422 are domestic capital while 202 are foreign. In 23 organizations there is an equal partnership. When the establishment date was investigated it was observed that 133 organizations were established before 1968; 126 were between 1968 and 1983; 130 were between 1984 and 1992; 133 were between 1993 and 2000; and 125 were established after 2000. Finally when the legal status of the organizations are examined, 574 are joint-stock companies; 48 are limited liability; and 25 are with other legal statutes.

\subsection{Demographics of Human Resource Managers}

The demographics of HR managers were examined under four sub-categories: gender, 


\section{Macrothink Mnstitute"}

International Journal of Human Resource Studies

ISSN 2162-3058

2017, Vol. 7, No. 4

education, total work experience and how they were appointed to current position. The demographics of HR managers can be seen on Table 2 .

Table 2. The demographics of HR managers

\begin{tabular}{|c|c|c|c|}
\hline & & $\mathrm{n}$ & $(\%)$ \\
\hline \multirow{2}{*}{ 1. Gender } & Female & 339 & 52,4 \\
\hline & Male & 308 & 47,6 \\
\hline \multicolumn{4}{|l|}{ 2. Education } \\
\hline \multirow{3}{*}{$\begin{array}{l}\text { 2.1. Associate } \\
\text { Bachelor's Degree }\end{array}$} & Associate degree & 13 & 2,0 \\
\hline & Bachelor's degree & 619 & 95,6 \\
\hline & Without associate or bachelor's degree & 15 & 2,4 \\
\hline \multirow{2}{*}{$\begin{array}{l}\text { The location of } \\
\text { the university }\end{array}$} & in Turkey & 613 & 97,0 \\
\hline & in a foreign country & 19 & 3,0 \\
\hline \multirow{2}{*}{$\begin{array}{l}\text { The status of the } \\
\text { university }\end{array}$} & Public & 596 & 94,3 \\
\hline & Private & 36 & 5,7 \\
\hline \multirow{7}{*}{ Faculty } & Business administration & 180 & 28,4 \\
\hline & Psychology / sociology / psychological counseling and g. & 74 & 11,7 \\
\hline & Economics & 72 & 11,4 \\
\hline & Engineering & 65 & 10,3 \\
\hline & International relations / political science & 60 & 9,5 \\
\hline & Labour economics and industrial relations & 44 & 7,0 \\
\hline & Other & 137 & 21,7 \\
\hline \multirow{3}{*}{ 2.2. Master's Degree } & With master's degree & 236 & 36,5 \\
\hline & Continuing master education & 32 & 5,0 \\
\hline & Without master's degree & 379 & 58,5 \\
\hline \multirow{2}{*}{$\begin{array}{l}\text { The location of } \\
\text { the university }\end{array}$} & in Turkey & 219 & 81,7 \\
\hline & in a foreign country & 49 & 18,3 \\
\hline \multirow{2}{*}{$\begin{array}{l}\text { The status of the } \\
\text { university }\end{array}$} & Public & 195 & 72,7 \\
\hline & Private & 73 & 27,3 \\
\hline \multirow{6}{*}{ Faculty } & MBA / business administration / economics & 93 & 34,7 \\
\hline & Human resource management & 68 & 25,4 \\
\hline & Organizational behaviour / management sciences & 39 & 14,5 \\
\hline & Educational sciences / philology & 14 & 5,2 \\
\hline & Industrial engineering & 9 & 3,4 \\
\hline & Other & 45 & 16,8 \\
\hline \multirow{3}{*}{ 2.3. Doctoral Degree } & With doctoral degree & 14 & 2,2 \\
\hline & Continuing doctoral education & 8 & 1,2 \\
\hline & Without doctoral degree & 625 & 96,6 \\
\hline \multirow{2}{*}{$\begin{array}{l}\text { The location of } \\
\text { the university }\end{array}$} & in Turkey & 21 & 95,0 \\
\hline & in a foreign country & 1 & 5,0 \\
\hline \multirow{2}{*}{$\begin{array}{l}\text { The status of the } \\
\text { university }\end{array}$} & Public university & 17 & 77,2 \\
\hline & Private university & 5 & 22,8 \\
\hline \multirow{5}{*}{ Faculty } & Management and organization / strategic management & 8 & 36,4 \\
\hline & Business administration & 3 & 13,6 \\
\hline & Physical sciences / chemistry / chemical engineering & 3 & 13,6 \\
\hline & Organizational behaviour & 2 & 9,1 \\
\hline & Other & 6 & 27,3 \\
\hline \multirow{5}{*}{$\begin{array}{l}\text { 3. } \quad \text { Total } \\
\text { Experience }\end{array}$} & 2 to 10 years & 138 & 21,3 \\
\hline & 11to 14 years & 136 & 21,0 \\
\hline & 15 to 17 years & 132 & 20,4 \\
\hline & 18 to 21 years & 121 & 18,7 \\
\hline & 22 years and more & 120 & 18,5 \\
\hline \multirow{3}{*}{$\begin{array}{l}\text { 4. How } \\
\text { Appointed }\end{array}$} & Promoted inside the organization & 250 & 38,6 \\
\hline & $\begin{array}{l}\text { Incoming from other organizations in the same group or } \\
\text { holding company }\end{array}$ & 36 & 5,6 \\
\hline & $\begin{array}{l}\text { Transferred from other organizations that belongs to a } \\
\text { different group or holding company }\end{array}$ & 361 & 55,8 \\
\hline TOTAL & & 647 & 100 \\
\hline
\end{tabular}


As seen in Table 2, 52,4\% of HR managers are female while 47,6\% are male. When the results are examined in terms of education, it is seen that 95,6\% have a Bachelor's Degree while 2\% have an Associate Degree. So, it can be concluded that the vast majority of HR managers have a Bachelor's Degree at least. Among 632 HR managers who have associate or Bachelor's Degree, 97\% received their degree from a domestic university while 3\% from a foreign. Additionally, 94,3\% received their degree from a public university while 5,7\% from a private. Also $28,4 \%$ received their degree in business administration, $11,4 \%$ in psychology and so on and $10,3 \%$ in engineering.

When the results are examined in terms of graduate education, 36,5\% of HR managers have a Master's Degree while 58,5\% have no Master's Degree. And 5\% are pursuing their master's degree education. $81,7 \%$ have completed or are pursuing Master's Degree in a domestic university while $18,3 \%$ in a foreign. When the locations of foreign universities are examined, it has been observed that 20 universities in the US, 12 in the UK, 6 in Germany, and 11 in other countries. Additionally, 72,7\% have completed or are pursuing a Master's Degree in a public university while $27,3 \%$ in a private. Also $34,7 \%$ have completed or are continuing Master's Degree in MBA, business administration or economics, 25,4\% in HRM, 14,5\% in organizational behaviour or management sciences, and $5,2 \%$ in educational sciences/philology. 2,2\% have a doctoral degree and 1,2\% are pursuing their doctoral education. $95 \%$ have completed or are pursuing doctoral education in a domestic university while $5 \%$ (one person) in Germany. Further, 77,2\% of HR managers have completed or are pursuing doctoral education in a public university while $22,8 \%$ in a private. When the results are examined in terms of the field of study, 36,4\% have completed or are pursuing doctoral education in management and organization or strategic management, 13,6\% in business administration, $13,6 \%$ in physical sciences, chemistry, or chemical engineering, and $9,1 \%$ in organizational behaviour. Finally, the classification of HR managers in terms of total work experience are as followed; $21,3 \%$ are between 2 and 10 years; $21 \%$ are between 11 and 14; $20,4 \%$ are between 15 and 17; 18,7\% are between 18 and 21 and 18,5\% are more than 21 years.

When the results are examined for how HR managers were appointed to current position, it is revealed that $38,6 \%$ were promoted to HR manager inside the organization while $55,8 \%$ were transferred to HR manager from other organizations that belongs to a different group or holding company.

\subsection{The Analysis of the Relationship between the Demographics of HR Managers and Characteristics of their Organizations}

Main purpose of this research is to find out whether there is a relation between the demographics of HR managers and the characteristics of organizations. In order to find out the relation, following hypotheses were developed and these hypotheses were tested and discussed in detail according to the results of the Chi-Square analysis.

$H_{1}$ : There is a relation between the segment in which organizations operate and the demographics of HR managers. 
In order to test this hypothesis Chi Square Analysis is conducted, and as a result of this, it has been concluded that there is a relation between the segment in which the organizations operate and the gender of HR managers $(0,000<0,05)$, the faculty from which they graduated in bachelor's degree $(0,001<0,05)$, whether they have a Master's Degree or not $(0,012<0,05)$, and how they are appointed to the current position $(0,046<0,05)$. In conclusion $\mathrm{H}_{1}$ hypothesis has been partially accepted. The results can be seen on Table 3 .

Table 3. Comparison of the segment in which the organizations operate with the demographics of HR managers

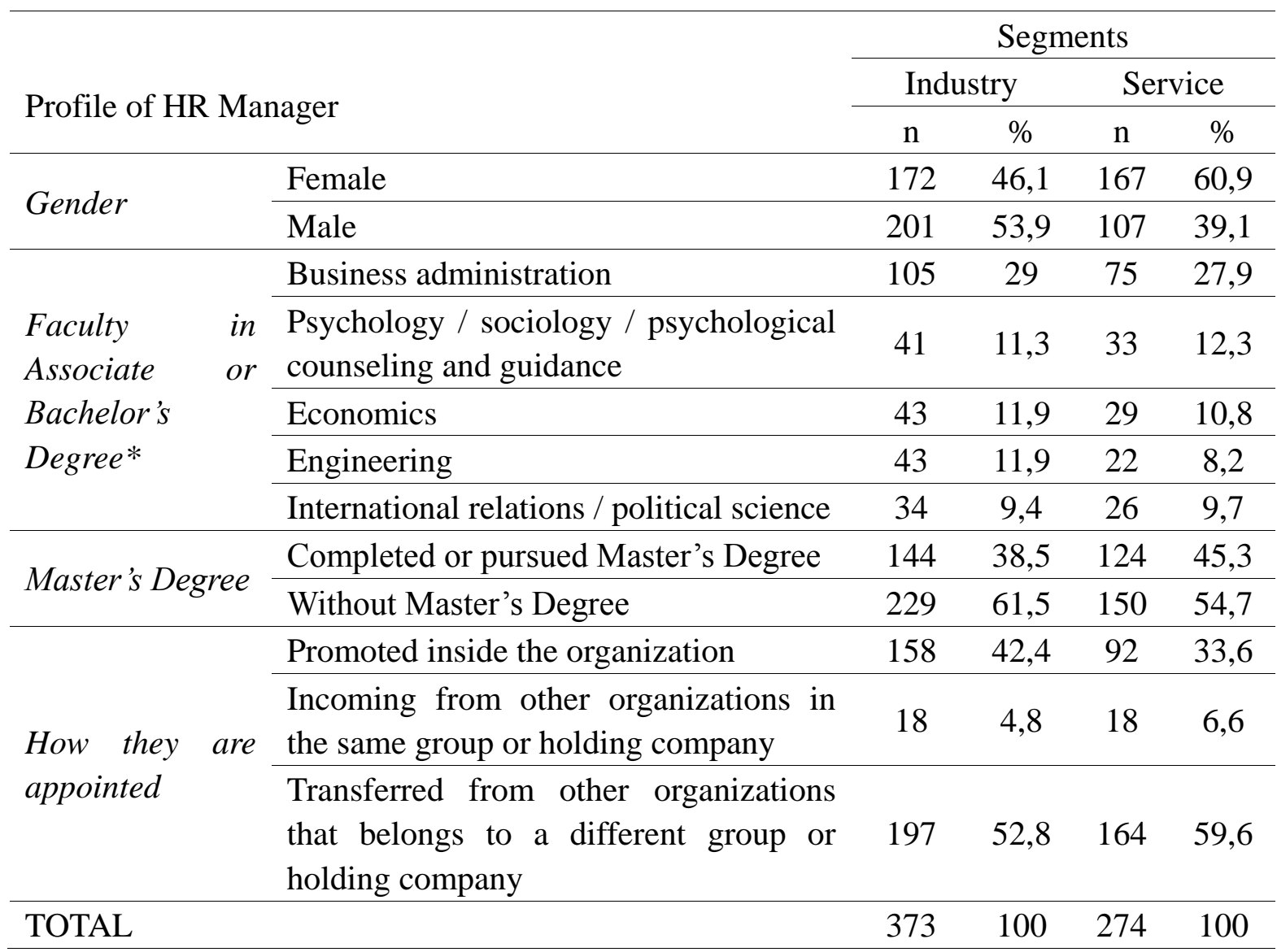

* Only top five categories were given place

When the results are examined; in industry segment mainly male HR managers are employed while in service sector it is mainly female; in industry segment HR managers mostly graduated with an associate or bachelor's degree in the fields of business administration, economics, and engineering; in service segment HR managers mostly graduated with an associate or Bachelor's Degree in the fields of business administration, psychology, etc.; the ratio of HR managers with a Master's Degree in service segment is higher than in industry segment; and finally HR managers were more frequently transferred from other organizations in service segment when compared to industry segment.

$\mathrm{H}_{2}$ : There is a relation between the sector of the organizations and the demographics of HR managers. 
As a result of Chi Square Analysis, it has been found out that there is relation between the sector of organizations and the gender of HR managers $(0,000<0,05)$, the faculty from which they graduated in bachelor's degree $(0,000<0,05)$, whether they have a Master's Degree or not $(0,048<0,05)$, total work experience $(0,000<0,05)$, and how they are appointed to the current position $(0,002<0,05)$. In conclusion $\mathrm{H}_{2}$ hypothesis has been partially accepted. The results can be seen on Table 4 .

Table 4. Comparison of the sector of the organizations with the demographics of HR managers

\begin{tabular}{|c|c|c|c|c|c|c|c|c|c|c|c|}
\hline \multirow{3}{*}{\multicolumn{2}{|c|}{ Profile of HR Manager }} & \multicolumn{10}{|c|}{ Sectors } \\
\hline & & \multicolumn{2}{|c|}{$\begin{array}{l}\text { Financial } \\
\text { Services }\end{array}$} & \multicolumn{2}{|c|}{$\begin{array}{c}\text { Metal } \\
\text { Products } \\
\text { Vehicles }\end{array}$} & \multicolumn{2}{|c|}{$\begin{array}{l}\text { Food, } \\
\text { Beverage } \\
\text { and Tob. }\end{array}$} & \multicolumn{2}{|c|}{$\begin{array}{l}\text { Petro-Che } \\
\text { mistry }\end{array}$} & \multicolumn{2}{|c|}{$\begin{array}{l}\text { Manifacturing } \\
\text { Industry }\end{array}$} \\
\hline & & $\mathrm{n}$ & $\%$ & $\mathrm{n}$ & $\%$ & $\mathrm{n}$ & $\%$ & $n$ & $\%$ & $n$ & $\%$ \\
\hline \multirow{2}{*}{ Gender } & Female & 47 & 51,1 & 40 & 49,4 & 25 & 39,1 & 47 & 75,8 & 24 & 38,7 \\
\hline & Male & 45 & 48,9 & 41 & 50,6 & 39 & 60,9 & 15 & 24,2 & 38 & 61,3 \\
\hline \multirow{5}{*}{$\begin{array}{l}\text { Faculty in } \\
\text { Associate } \\
\text { or } \\
\text { Bachelor's } \\
\text { Degree* }\end{array}$} & $\begin{array}{l}\text { Business } \\
\text { administration }\end{array}$ & 32 & 35,2 & 24 & 30,8 & 17 & 27,4 & 12 & 19,4 & 16 & 26,7 \\
\hline & $\begin{array}{l}\text { Psychology, } \\
\text { sociology, } \\
\text { psychological } \\
\text { couns. }\end{array}$ & 8 & 8,8 & 8 & 10,3 & 8 & 12,9 & 15 & 24,2 & 3 & 5,0 \\
\hline & Economics & 11 & 12,1 & 5 & 6,4 & 13 & 21,0 & 5 & 8,1 & 7 & 11,7 \\
\hline & Engineering & 13 & 14,3 & 13 & 16,7 & 8 & 12,9 & 4 & 6,5 & 11 & 18,3 \\
\hline & $\begin{array}{l}\text { International } \\
\text { relations, Political } \\
\text { science }\end{array}$ & 12 & 13,2 & 10 & 12,8 & 3 & 4,8 & 9 & 14,5 & 4 & 6,7 \\
\hline \multirow{2}{*}{$\begin{array}{l}\text { Master's } \\
\text { Degree }\end{array}$} & $\begin{array}{l}\text { Completed } \text { or } \\
\text { pursued Master's } \\
\text { Degree }\end{array}$ & 44 & 47,8 & 32 & 39,5 & 23 & 35,9 & 33 & 53,2 & 21 & 33,9 \\
\hline & $\begin{array}{l}\text { Without Master's } \\
\text { Degree }\end{array}$ & 48 & 52,2 & 49 & 60,5 & 41 & 64,1 & 29 & 46,8 & 41 & 66,1 \\
\hline \multirow{5}{*}{$\begin{array}{l}\text { Total work } \\
\text { experience }\end{array}$} & 2 and 10 years & 3 & 3,3 & 20 & 24,7 & 20 & 31,3 & 12 & 19,4 & 13 & 21,0 \\
\hline & 11 and 14 years & 17 & 18,5 & 14 & 17,3 & 6 & 9,4 & 14 & 22,6 & 11 & 17,7 \\
\hline & 15 and 17 years & 16 & 17,4 & 18 & 22,2 & 14 & 21,9 & 14 & 22,6 & 12 & 19,4 \\
\hline & 18 and 21 years & 25 & 27,2 & 12 & 14,8 & 9 & 14,1 & 11 & 17,7 & 12 & 19,4 \\
\hline & 22 years and more & 31 & 33,7 & 17 & 21,0 & 15 & 23,4 & 11 & 17,7 & 14 & 22,6 \\
\hline \multirow{3}{*}{$\begin{array}{l}\text { How they } \\
\text { are } \\
\text { appointed }\end{array}$} & $\begin{array}{l}\text { Promoted inside } \\
\text { the organization }\end{array}$ & 43 & 46,7 & 42 & 51,9 & 25 & 39,1 & 20 & 32,3 & 24 & 38,7 \\
\hline & $\begin{array}{l}\text { Incoming from } \\
\text { other } \\
\text { organizations in } \\
\text { the same groups }\end{array}$ & 5 & 5,4 & 2 & 2,5 & 5 & 7,8 & 4 & 6,5 & 4 & 6,5 \\
\hline & $\begin{array}{l}\text { Transferred from } \\
\text { other } \\
\text { organizations that } \\
\text { belongs to a } \\
\text { different groups }\end{array}$ & 44 & 47,8 & 37 & 45,7 & 34 & 53,1 & 38 & 61,3 & 34 & 54,8 \\
\hline TOTAL & & 92 & 100 & 81 & 100 & 64 & 100 & 62 & 100 & 62 & 100 \\
\hline
\end{tabular}

* Only top five categories were given place 
When the results are examined; mainly female HR managers are employed in finance and petro-chemistry sectors while it is mainly male in food, beverage and tobacco and manifacturing sectors. In the metal products-vehicles sector, it is seen that the number of male HR managers are more than female HR managers although rates are very close to each other. The number of HR managers with Associate or Bachelor's Degree in psychology and so on in petro-chemistry sector and in economics in food, beverage and tobacco sectors is relatively large. The number of HR managers with a Master's Degree is less than the number of HR managers without a Master's Degree in all sectors, except petro-chemistry sector. Additionally, HR managers who completed or pursued Master's Degree are dominantly in finance sector, and at the least in basic metal industry-energy sector. When the results are examined in terms of total work experience, it is observed that HR managers in finance sector are more senior compared to HR managers in other sectors. On the other hand the distribution in terms of total work experience of HR managers is more balanced in other sectors. And finally in terms of how HR managers are appointed to their current position, it is seen that HR managers are dominantly transferred from other businesses in all sectors (mostly in petro-chemistry, at the least in finance sector), with an exception in metal products-vehicles.

$H_{3}$ : There is a relation between the partnership structure of the organizations and the demographics of HR managers.

As a result of Chi Square Analysis, it has been detected that there is relation between the partnership structure of the organizations and the gender of HR managers $(0,000<0,05)$ and the faculty from which they graduated in Bachelor's Degree $(0,000<0,05)$. In conclusion $\mathrm{H}_{3}$ hypothesis has been partially accepted. The results can be seen on Table 5 .

Table 5. Comparison of the partnership structure of the organizations with the demographics of HR managers

\begin{tabular}{|c|c|c|c|c|c|c|c|c|}
\hline \multirow{3}{*}{\multicolumn{3}{|c|}{ Profile of HR Manager }} & \multicolumn{6}{|c|}{ Partnership Structure } \\
\hline & & & \multicolumn{2}{|c|}{$\begin{array}{c}\text { Domestic-ow } \\
\text { ned }\end{array}$} & \multicolumn{2}{|c|}{$\begin{array}{l}\text { Foreign-o } \\
\text { wned }\end{array}$} & \multicolumn{2}{|c|}{$\begin{array}{l}\text { Equally-o } \\
\text { wned }\end{array}$} \\
\hline & & & $\mathrm{n}$ & $\%$ & $\mathrm{n}$ & $\%$ & $\mathrm{n}$ & $\%$ \\
\hline \multirow{2}{*}{\multicolumn{2}{|c|}{ Gender }} & Female & 190 & 45 & 136 & 67,3 & 13 & 56,5 \\
\hline & & Male & 232 & 55 & 66 & 32,7 & 10 & 43,5 \\
\hline \multirow{5}{*}{$\begin{array}{l}\text { Faculty } \\
\text { Associate } \\
\text { Bachelor's } \\
\text { Degree* }^{*}\end{array}$} & & Business administration & 131 & 31,9 & 42 & 21,3 & 7 & 30,4 \\
\hline & $\begin{array}{l}\text { in } \\
\text { or }\end{array}$ & $\begin{array}{l}\text { Psychology / sociology / } \\
\text { psychological counseling and } \\
\text { guidance }\end{array}$ & 32 & 7,8 & 40 & 20,3 & 2 & 8,7 \\
\hline & & Economics & 47 & 11,4 & 22 & 11,2 & 3 & 13,0 \\
\hline & & Engineering & 38 & 9,2 & 23 & 11,7 & 4 & 17,4 \\
\hline & & $\begin{array}{l}\text { International relations } \\
\text { political science }\end{array}$ & 40 & 9,7 & 18 & 9,1 & 2 & 8,7 \\
\hline TOTAL & & & 422 & 100 & 202 & 100 & 23 & 100 \\
\hline
\end{tabular}

* Only top five categories were given place

When the results are examined; dominantly male HR managers are employed in domestic capital organizations, while mainly female in foreign-owned and equally-owned businesses; considering the HR managers working in all organizations in all three partnership structure, HR 
managers mostly have Associate or Bachelor's Degree in business administration. And finally economics in domestic-owned businesses, psychology and so on in foreign capital businesses and engineering in equally-owned businesses are in second place after business administration.

$H_{4}$ : There is a relation between the year of establishment of the organizations and the demographics of HR managers.

The results of Chi Square Analysis revealed that there is relation between the year of establishment of the organizations and the demographics of HR managers which is; gender $(0,020<0,05)$, the faculty from which they graduated in Bachelor's Degree $(0,022<0,05)$, whether they have a Master's Degree or not $(0,036<0,05)$, and how they are appointed to their current position $(0,002<0,05)$. As a result $\mathrm{H}_{5}$ hypothesis has been partially accepted. The results can be seen on Table 6 .

Table 6. Comparison of the year of establishment of the organizations with the demographics of HR managers

\begin{tabular}{|c|c|c|c|c|c|c|c|c|c|c|c|}
\hline \multirow{3}{*}{\multicolumn{2}{|c|}{ Profile of HR Manager }} & \multicolumn{10}{|c|}{ Year of Establishment } \\
\hline & & \multicolumn{2}{|c|}{$\begin{array}{c}1967 \text { and } \\
\text { before }\end{array}$} & \multicolumn{2}{|c|}{$\begin{array}{c}1968 \text { and } \\
1983\end{array}$} & \multicolumn{2}{|c|}{$\begin{array}{c}1984 \text { and } \\
1992\end{array}$} & \multicolumn{2}{|c|}{$\begin{array}{c}1993 \text { and } \\
2000\end{array}$} & \multicolumn{2}{|c|}{$\begin{array}{l}2000 \text { and } \\
\text { after }\end{array}$} \\
\hline & & $\mathrm{n}$ & $\%$ & $\mathrm{n}$ & $\%$ & $\mathrm{n}$ & $\%$ & $\mathrm{n}$ & $\%$ & $\mathrm{n}$ & $\%$ \\
\hline \multirow{2}{*}{ Gender } & Female & 57 & 42,9 & 65 & 51,6 & 63 & 48,5 & 82 & 61,7 & 72 & 57,6 \\
\hline & Male & 76 & 57,1 & 61 & 48,4 & 67 & 51,5 & 51 & 38,3 & 53 & 42,4 \\
\hline \multirow{5}{*}{$\begin{array}{l}\text { Faculty in } \\
\text { Associate } \\
\text { or } \\
\text { Bachelor's } \\
\text { Degree* }\end{array}$} & $\begin{array}{l}\text { Business } \\
\text { administration }\end{array}$ & 39 & 29,5 & 29 & 24,0 & 40 & 31,7 & 35 & 26,9 & 37 & 30,3 \\
\hline & $\begin{array}{ll}\text { Psychology } & \text { / } \\
\text { sociology } & / \\
\text { psychological } \\
\text { couns. }\end{array}$ & 10 & 7,6 & 15 & 12,4 & 13 & 10,3 & 21 & 16,2 & 15 & 12,3 \\
\hline & Economics & 13 & 9,8 & 11 & 9,1 & 14 & 11,1 & 15 & 11,5 & 19 & 15,6 \\
\hline & Engineering & 18 & 13,6 & 16 & 13,2 & 14 & 11,1 & 10 & 7,7 & 7 & 5,7 \\
\hline & $\begin{array}{l}\text { International } \\
\text { relations } \\
\text { political science }\end{array}$ & 16 & 12,1 & 12 & 9,9 & 9 & 7,1 & 10 & 7,7 & 13 & 10,7 \\
\hline \multirow{2}{*}{$\begin{array}{l}\text { Master's } \\
\text { Degree }\end{array}$} & $\begin{array}{l}\text { Completed or } \\
\text { pursued master's } \\
\text { degree }\end{array}$ & 59 & 44,4 & 52 & 41,3 & 43 & 33,1 & 55 & 41,4 & 59 & 47,2 \\
\hline & $\begin{array}{l}\text { Without master's } \\
\text { degree }\end{array}$ & 74 & 55,6 & 74 & 58,7 & 87 & 66,9 & 78 & 58,6 & 66 & 52,8 \\
\hline \multirow{3}{*}{$\begin{array}{l}\text { How they } \\
\text { are } \\
\text { appointed }\end{array}$} & $\begin{array}{l}\text { Promoted inside } \\
\text { the organization }\end{array}$ & 67 & 50,4 & 53 & 42,1 & 49 & 37,7 & 52 & 39,1 & 29 & 23,2 \\
\hline & $\begin{array}{l}\text { Incoming from } \\
\text { other } \\
\text { organizations in } \\
\text { the same group }\end{array}$ & 9 & 6,8 & 4 & 3,2 & 8 & 6,2 & 9 & 6,8 & 6 & 4,8 \\
\hline & $\begin{array}{l}\text { Transferred from } \\
\text { other } \\
\text { organizations that } \\
\text { belongs to a } \\
\text { different group }\end{array}$ & 57 & 42,9 & 69 & 54,8 & 73 & 56,2 & 72 & 54,1 & 90 & 72,0 \\
\hline TOTAL & & 133 & 100 & 126 & 100 & 130 & 100 & 133 & 100 & 125 & 100 \\
\hline
\end{tabular}

* Only top five categories were given place 


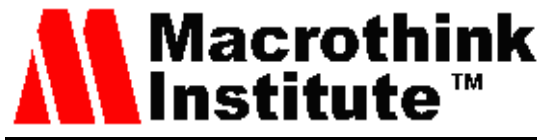

When the results are examined; male HR managers are dominantly employed in older companies, while in younger predominantly female HR managers. When the faculty that HR managers graduated with Associate or Bachelor's Degree are examined, the HR managers in companies established in different time periods mainly have a business administration degree. However, the number of engineering graduates in older organizations and the number of ecomonics graduates in younger businesses are relatively high. When the results are analyzed in terms of Master's Degree, the ratio of HR managers who hold a Master's Degree is less compared to those that do not. However, the ratio of HR managers with a Master's Degree is highest in organizations established after 2000, while it is lowest in organizations established between 1984 and 1992. Finally when the organizations are analyzed in terms of how the HR managers are appointed to their current positions; in all companies established after 1968 (being highest in the firms that were established after 2000 and lowest in established between 1993 and 2000) HR managers mostly transferred from other organizations. On the contrary, in companies established before 1967, HR managers mostly promoted inside the organization.

$H_{5}$ : There is a relation between the legal status of the organizations and the demographics of HR managers.

The results of Chi Square Analysis revealed that there is relation only between the legal status of the organizations and how HR managers are appointed to their current position $(0,038<0,05)$. As a result $\mathrm{H}_{6}$ hypothesis has been partially accepted. The results can be seen on Table 7.

Table 7. Comparison of the legal status of the organizations with the demographics of HR managers

\begin{tabular}{|c|c|c|c|c|c|c|c|}
\hline \multirow{3}{*}{\multicolumn{2}{|c|}{ Profile of HR Manager }} & \multicolumn{6}{|c|}{ Legal Status } \\
\hline & & \multicolumn{2}{|c|}{ Joint-stock } & \multicolumn{2}{|c|}{ Limited } & \multicolumn{2}{|c|}{ Other } \\
\hline & & $\mathrm{n}$ & $\%$ & $\mathrm{n}$ & $\%$ & $\mathrm{n}$ & $\%$ \\
\hline \multirow{3}{*}{$\begin{array}{l}\text { How they } \\
\text { are } \\
\text { appointed }\end{array}$} & Promoted inside the organizations & 230 & 40,1 & 13 & 27,1 & 7 & 28,0 \\
\hline & $\begin{array}{l}\text { Incoming from other organizations } \\
\text { in the same group or holding } \\
\text { company }\end{array}$ & 33 & 5,7 & 0 & 0 & 3 & 12,0 \\
\hline & $\begin{array}{l}\text { Transferred from } \\
\text { organizations that belongs to a } \\
\text { different group or holding company }\end{array}$ & 311 & 54,2 & 35 & 72,9 & 15 & 60,0 \\
\hline TOTAL & & 574 & 100 & 48 & 100 & 25 & 100 \\
\hline
\end{tabular}

When the results are examined, HR managers are mostly transferred from other organizations that belongs to a different group or holding company in organizations with all legal statutes. However the ratio of HR managers who are promoted inside the organizations in joint-stock companies is higher than in limited liability companies.

\section{Conclusion}

The main purpose of this study, which is conducted through analyzing the publicly available data obtained from secondary sources, is to determine whether there exists any relations 
between demographics of HR managers demographics and characteristics of their organizations in Turkey. This is a wide range study in which a total of 647 organizations and their HR managers from 22 different sectors are investigated. It is hoped that this study presents a broader picture about demographics of HR managers in Turkey and may contribute to the literature with the findings revealed.

In the conclusion of the research it has been discovered that more than half of the HR managers are female; a great majority of the HR managers holds at least Bachelor's Degree; and business administration is the most common field in Bachelor's Degree. Besides almost half of the HR managers either have or pursuing a Master's Degree while the most preferred programs are MBA, business administration or economics. According to the results of the study, a small number of HR managers have doctoral degree or are pursuing doctoral education and the most preferred programs are management and organization or strategic management. Other results of this study are; approximately $60 \%$ of the HR managers have less than 15 years of total work experience; more than half of them are transferred from other organizations that belong to a different group or holding company. When the findings of similar studies conducted in different countries are compared, female HR managers are higher in number in Turkey. Additionally when compared with the study by Uyargil and Özçelik (2001) it can be stated that the number of female HR managers has increased. Furthermore, the ratio of HR managers with Bachelor's Degree in Turkey is higher than other countries; while the ratio of Doctoral Degree is similar. The reason behind the higher number of HR managers with Bachelor's Degree in business administration may be due to the fact that most HR managers in industry sector and relatively smaller organizations are graduates of business administration department of Open Education Faculty in Anadolu University. Additionally the assumption that graduates of departments such as psychology and sociology prefer HR field more frequently in recent years is verified in this research. However; it is interesting that when compared to Bachelor's Degree, HR managers predominantly prefer foreign or private universities for Master's and Doctoral education. It can be supposed that non-thesis master's programs in private universities and the flexibility in terms of attendance are the reasons behind this finding. Additionally it can be deduced that instead of being trained and promoted inside the organizations, most of the HR managers in Turkey are transferred from other organizations. Among many reasons of this, some might be as follows; the replacement of hierarchic organization structures with fewer staged, team work and project oriented organizational structure; preference of organizations to find and transfer qualified managers instead of starting employees from the lowest stage and training themin order for them to rise vertically in a hierarchic structure and become managers.

In the scope of this study, the demographics of HR managers and the characteristics of the organizations are compared for the purpose of determining whether there is a relation between them. As a result, it has been observed that HR managers are mostly male in industrial companies, while predominantly female HR managers are employed in service companies. The result can be viewed as significant considering the fact that mainly female HR Managers are employed in service companies. Additionally, it is interesting that the number of female HR managers is comparatively higher in the chemistry-petroleum sector. 
This finding is believed to be due to the ratio of HR managers in the global medicine sector which is the pioneer of the modern management, and in which first traces of modern practices are observed. Foreign capital organizations or equally shared ones, and the organizations which are established in relatively closer dates employs mostly female HR managers. When the variable of education background is considered, it has been observed that HR managers in the industrial companies have Bachelor's Degree in business administration, while HR Managers in the service companies have bachelor's degree from psychology and so on along with business administration. Another important finding of the study is that ratio of Master's Degrees in the service sector is higher than in the industry. Besides, the ratio of Master's Degree in chemistry-petroleum sector is high. This finding may be the result of the fact that HR managers in this sector are mainly from technical departments, and among the graduates of these departments, having an MBA degree after undergraduate education is considered important. Nevertheless, the number of HR managers that holds Bachelor's Degree in psychology and so on is also high in foreign organizations in accordance with the examples in the world. The establishment dates of the businesses are also taken into consideration and the results are found similar to earlier studies; mostly graduates of engineering are working as HR managers in relatively older organizations, while in newer companies in addition to business administration or economics, graduates of other departments such as psychology and so on are employed. Furthermore, the ratio of HR managers that holds or pursues a Master's Degree is higher in newer organizations. When the results are evaluated as a whole, a general picture towards HRM can be extracted particularly from the point of being a domestic/foreign based organization or older/newer found organization. A new generation in HR management has emerged in Turkey that is composed predominantly of females, that are the graduates of best universities in Turkey, and have the knowledge of one or two foreign languages; international organizations, or relatively new organizations mostly prefer HR managers from this new generation. On the other hand, it can be stated for domestic, or relatively older organizations that they consider they do not have to change their current HR managers and/or they mostly employ traditional HR managers. When the results on how HR managers are appointed to their current position are examined, it has been concluded that the service companies compared to industrial companies transfer HR managers more often from other organizations. This finding might be considered as significant due to that fact that competition is heavier in service sector and for this reason they have to choose HR managers from among the "new generation" in order to be more competitive. In addition to this, it has been found that particularly the organizations established after 2000 mostly transferred the HR managers from other organizations, while the ones established in 1967 or before used promotion. The results describes a meaningful fact that; HRM discipline has improved through time, relatively new companies are flatter organizations compared to the traditional ones, and they have simple structures instead of a hierarchic structure; new organizations mostly prefer finding and transferring qualified HR managers rather than training and promoting them in a hierarchic structure; there are more alternatives for HR manager position when compared to the past and transfers of executives are more common today.

Since there is not enough studies that concerns the determining of HR demographics or testing the relation between demographics of $\mathrm{HR}$ managers and characteristics of 
organizations, this study may contribute to the literature with the findings revealed. Moreover, an overall picture of HR demographics in Turkey was taken with this study. In future studies it is recommended to expand the scope to reach a higher number of organizations and HR managers; to use survey method to get more detailed information; and to focus on group interviews.

\section{References}

Antila, E. M. (2006). The role of HR managers in international mergers and acquisitions: A multiple case study. International Journal of Human Resource Management, 17(6), 999-1020. https://doi.org/10.1080/09585190600693322

Armstrong, M. (2009). Armstrong's handbook of human resource management practice. London: Kogan Page.

Azmi, F. T., \& Mushtaq, S. (2015). Role of line managers in human resource management: Empirical evidence from India. The International Journal of Human Resource Management, 26(5), 616-639. https://doi.org/10.1080/09585192.2014.934883

Beardwell, J., \& Claydon, T. (2010). Human resource management: A contemporary approach. London: Pearson Education.

Bos-Nehles, A. C., Van Riemsdijk, M. J., \& Looise, J. K. (2013). Employee perceptions of line management performance: Applying the AMO theory to explain the effectiveness of line managers' HRM implementation. Human Resource Management, 52(6), 861-877. https://doi.org/10.1002/hrm.21578

Brewster, C., Wood, G., Brookes, M., \& Van Ommeren, J. (2006). What determines the size of the HR function? A crossnational analysis. Human Resource Management, 45(1), 3-21. https://doi.org/10.1002/hrm.20093

Demirtaş, Ö. (2013). Stratejik insan kaynakları yönetimi ve örgütsel inovasyon. Marmara University Journal of Economic and Administrative Sciences, 35(2), 261-290. https://doi.org/10.14780/iibdergi.201324467

Demirtaş, Ö. (2014). Stratejik insan kaynakları yönetiminin örgütsel ve bireysel düzeyde etkileri. Hacettepe University Journal of Economics and Administrative Sciences, 32(2), 75-101. https://doi.org/10.17065/huiibf.93737

Dessler, G. (2011). Human resource management. New Jersey: Pearson Education.

Giannantonio, C. M., \& Hurley, A. E. (2002). Executive insights into HR practices and education. Human Resource Management Review, 12(4), 183-208. https://doi.org/10.1016/S1053-4822(02)00074-8

Gürbüz, S. (2011). Stratejik insan kaynakları yönetiminin örgütsel bağlılığa ve iş tatminine etkisi: İnsan kaynakları yöneticileri üzerinde bir araştırma. Atatürk University Journal of Social Sciences Institute, 15(2), 397-418. Retrieved from: http://e-dergi.atauni.edu.tr/atauni sosbil/article/viewFile/1020007667/1020006831 


\section{Macrothink}

International Journal of Human Resource Studies

ISSN 2162-3058

2017, Vol. 7, No. 4

Heery, E., \& Noon, M. (2008). A dictionary of human resource management. New York: Oxford University Press. https://doi.org/10.1093/acref/9780199298761.001.0001

Human Resources Professionals Association. (2009). Audience demographics. Retrieved from http://www.hrpa.ca/AdvertisingSponsorship/Pages/AudienceDemographics.aspx

Ivancevich, J. M. (2010). Human resource management. New York: McGraw Hill.

Jamshidi, M. H., Zeinahvazi, M., Aadal, H., \& Sabet, P. G. P. (2012). Essential competencies for the human resource managers and professionals in construction industries. Journal of Basic and Applied Scientific Research, 2(10), 10296-10302. Retrieved from: https://www.researchgate.net/profile/Mir_Hadi_Jamshidi/publication/251571294_Essential_ Competencies_for_the_Human_Resource_Managers_and_Professionals_in_Construction_In dustries/links/00b7d51f0e4898edac000000.pdf?origin=publication_detail

Kochan, T. A. (2004). Restoring trust in the human resource management profession, MIT institute for work \& employment research. Retrieved from: http://web.mit.edu/ workplacecenter/docs/WPC\%230013.pdf

Long, C. S. (2008). Examining human resource competencies and their relationship to the success factors of HR profession. Journal of Service Science and Management, 1, 259-265. https://doi.org/10.4236/jssm.2008.13029

Margrit, S. (2012). Qualitative content analysis in Practice. London: Sage Publications.

Mitchell, R., Obeidat, S., \& Bray, M. (2013). The effect of strategic human resource management on organizational performance: The mediating role of high-performance human resource practices. Human Resource Management, 52(6), 899-921. https://doi.org/10.1002/hrm.21587

Ngo, H. Y., Lau, C. M., \& Foley, S. (2008). Strategic human resource management, firm performance, and employee relations climate in China. Human Resource Management, 47(1), 73-90. https://doi.org/10.1002/hrm.20198

Noe, R. A., Hollenbeck, J. R., Gerhart, B., \& Wright, P. M. (2008). Human resources management. New York: McGraw Hill.

OneDergi. (2010). İnsan kaynaklarının etkinliği artacak. Retrieved from: http://www.onedergi.com/2010/08/insan-kaynaklarinin-etkinligi-artacak/

Özutku, H., \& Çetinkaya, M. (2012). İnsan kaynakları yönetiminde hat yöneticilerin rolüne ilişkin bir çalışma. Journal of Akademic Sight, 30, 1-21. Retrieved from http://www.acarindex.com/dosyalar/makale/acarindex-1423868005.pdf

Page, M. (2013). Global HR barometer 2013. Michael Page International, Retrieved from: http://www.michaelpage.de/productsApp_de/MiniSites/barometer2013/pdf/HR_Barometer_ MP_2013_EN_final.pdf

Piening, E. P., Baluch, A. M., \& Ridder, H. G. (2014). Mind the intended-implemented gap: Understanding employees' perceptions of HRM. Human Resource Management, 53(4), 
545-567. https://doi.org/10.1002/hrm.21605

Prudnikova, K., \& Demidova, O. (2015). The role of HR-manager in the effective management of human resources. Journal of Economics and Social Sciences, 6, 1-4.

Sumelius, J., Björkman, I., Ehrnrooth, M., Mäkelä, K., \& Smale, A. (2014). What determines employee perceptions of HRM process features? The case of performance appraisal in MNC subsidiaries. Human Resource Management, 53(4), 569-592. https://doi.org/10.1002/hrm.21604

Tastard, J. (2012). Creating a high performance culture: A study of the perceptions of human resource executives. (Unpublished doctoral dissertation thesis). Capella University, Minneapolis, USA.

The RBL Group. (2007). Human resource competency study executive summary. Retrieved from http://www.gapinchr.rbl.net/resources/HRCS\%20Executive\%20Summary.pdf

Torrington, D., Hall, L., \& Taylor, S. (2008). Human resouırces management. New Jersey: Prentice Hall.

Uyargil, C., \& Özçelik, O. (2012, June). Some characteristics of the Turkish HR managers/professionals and a comparative study with three European countries (United Kingdom, Germany and Spain). Human Resources Global Management Conference, Barcelona, Spain.

Vermeeren, B. (2014). Variability in HRM implementation among line managers and its effect on performance: A 2-1-2 mediational multilevel approach. The International Journal of Human Resource Management, $\quad$ 25(22), 3039-3059. https://doi.org/10.1080/09585192.2014.934891

Yılmaz, H., \& Karahan, A. (2014). Yüksek performanslı insan kaynakları yönetimi uygulamaları, psikolojik güçlendirme ve duygusal bağlılık arasındaki ilişkilerin incelenmesi: Tekstil sektöründe bir araştırma. Dokuz Eylül University Journal of Graduate School of Social Sciences, 16(4), 607-637. https://doi.org/10.16953/deusbed.62106

Yılmaz, Y., \& Ömürgönülşen, M. (2013). İnsan kaynakları yönetimi uygulamalarının algılanmasının üretim performansı algısı üzerindeki etkisi: Bir örnek olay çalışması. Hacettepe University Journal of Economics and Administrative Sciences, 31(2), 197-228. doi: http://dx.doi.org/10.17065/huiibf.77516

\section{Copyright Disclaimer}

Copyright for this article is retained by the author(s), with first publication rights granted to the journal.

This is an open-access article distributed under the terms and conditions of the Creative Commons Attribution license (http://creativecommons.org/licenses/by/4.0/). 